\title{
Analisis Kemampuan Mahasiswa dalam Pengembangan RPP Mata Pelajaran Kimia Melalui Pendekatan Saintifik
}

\section{Analysis of Student Ability in the Development of Chemistry Lesson Plan Through a Scientific Approach}

\author{
Lenni Khotimah Harahap ${ }^{1^{*}}$, Sri Rahmania ${ }^{1}$ \\ ${ }^{1}$ Program Studi Pendidikan Kimia Universitas Islam Negeri (UIN) Walisongo Semarang
}

\section{A B S T R A K}

Sebelum melaksanakan pembelajaran, guru harus terlebih dahulu mempersiapkan dan merencanakan perangkat pembelajaran yang salah satunya adalah RPP, dimana mahasiswa Pendidikan Kimia Uin Walisongo Semarang sebagai calon guru harus mampu menyusun perangkat pembelajaran sebagai bekal nantinya ketika memasuki dunia kerja. Tujuan dari penelitian ini adalah menganalisis pendekatan saintifik dalam tahapan kegiatan pembelajaran penyusunan RPP mata pelajaran kimia oleh mahasiswa yang mengambil matakuliah Perencanaan Pembelajaran. Populasi dalam penelitian ini adalah seluruh mahasiswa Pendidikan Kimia Uin Walisongo Semarang semester 5 yang mengambil matakuliah Perencanaan Pembelajaran. Sampel dalam penelitian ini yakni 25 mahasiswa. Instrumen pengumpul data berupa angket analisis pendekatan saintifik penyusunan RPP. Berdasarkan hasil penelitian dan pembahasan diperoleh bahwa dari 25 sampel menunjukkan kemampuan pada tahap mengamati yakni $83 \%$, menanya $80 \%$, mengumpulkan informasi 75\%, mengasosiasikan/mengolah informasi $76 \%$ dan mengkomunikasikan $81 \%$.

\section{$A B S T R A C T$}

Before teaching, teachers must prepare and make learning tools, one of which is the lesson plan. Chemistry Education students at Uin Walisongo Semarang as prospective teachers must prepare lesson plans later when entering the work. This study aimed to analyze the scientific approach in the stages of learning activities for the preparation of lesson plans for chemistry subjects by students taking the lesson planning course. This study population was all 5th-semester college students of Chemistry Education at Uin Walisongo Semarang who took the lesson planning course. The sample in this study was 25 students. The data collection instrument was in the form of a scientific approach analysis questionnaire to prepare lesson plans. Based on the research and discussion results, it was found that 25 samples showed in the observing get $83 \%$ score, ask to get $80 \%$ score, gathering information get $75 \%$ score, associating/processing information get $76 \%$ score, and communicating get $81 \%$ score.

Kata kunci/Keyword : pendekatan saintifik; RPP Kimia; learning activities; scientific approach; chemistry lesson plan.

I N F O A R T I K E L

Received: 19 Nov 2020;

* coresponding author: lenniharahap@walisongo.ac.id

Revised: 10 Dec 2020;

DOI: https://doi.org/10.22437/jisic.v12i2.11072

Accepted: 12 Dec 2020 


\section{PENDAHULUAN}

Suatu organisasi pendidikan yang berkualitas tentunya memiliki sistem manajemen yang baik. Melalui manajemen yang baik setiap komponen pendidikan akan dapat bersinergi dengan baik guna memberikan layanan yang optimal untuk mencapai tujuan bersama. Dalam lembaga pendidikan, setiap unsur pelaksana pendidikan harus dikelola dengan menggunakan konsep dan prinsip-prinsip manajemen demi terjaminnya mutu pendidikan.

Pendidikan adalah upaya sadar dan terencana untuk menciptakan suasana belajar dan proses belajar bagi peserta didik agar dapat secara aktif mengembangkan potensi, pengendalian diri, kepribadian, kecerdasan, karakter, dan keterampilannya (Depdikbud, 2014).

Salah satu perangkat pendidikan yaitu guru yang bertugas untuk mendidik siswa terutama pada saat didalam kelas dimana ketika akan mengajar guru dituntun untuk lebih dahulu membuat perencanaan dalam bentuk perangkat pembelajaran. Perangkat pembelajaran memiliki fungsi agar segala aktivitas guru dalam pembelajaran telah terencana dengan baik sehingga bisa lebih efisien dan efektif. Guru dituntut untuk membuat perencanaan dalam bentuk rencana pelaksanaan pembelajaran (RPP).

RPP merupkan suatu rencana kegiatan pembelajaran yang harus dipersiapkan oleh guru sebelum melakukan pembelajaran. RPP dikembangkan berdasarkan silabus sebagai panduan dalam merancang kegiatan pembelajaran dalam upaya mencapai Kompetensi Dasar (KD) yang diinginkan dari peserta didik. Setiap guru pada satuan pendidikan berkewajiban menyusun RPP secara lengkap dan sistematis sebelum pembelajaran berlangsung dengan tujuan agar pembelajaran berlangsung secara efektif, efisien dan menyenangkan serta mampu memotivasi siswa untuk berperan aktif dalam pembelajaran sehingga mampu memaksimalkan potensi yang ada dalam dirinya.
Beberapa komponen yang ada pada RPP salah satunya yaitu pelaksanaan pembelajaran atau tahapan kegiatan pembelajaran. Kegiatan pembelajaran merupakan implementasi dari RPP, meliputi kegiatan pendahuluan, inti dan penutup. Implementasi kurikulum 2013 sangat menonjolkan pendekatan saintifik. Perangkat pembelajaran dengan pendekatan saintifik merupakan pembelajaran yang berpusat pada peserta didik. Terdapat banyak perangkat pembelajaran yang dikembangkan melalui pendekatan saintifik yang menunjukkan bahwa perangkat pembelajaran seperti media dan LKPD yang dikembangkan dengan pendekatan saintifik layak untuk digunakan dalam pembelajaran serta mampu memotivasi siswa dalam pembelajaran (Amalia, Naswir, \& Harizon, 2020; Apriyanto, Yusnelti, \& Asrial, 2019).

Kegiatan pembelajaran saintifik diadopsi berdasarkan langkah-langkah saintifik dalam menemukan dan membangun sebuah konsep pengetahuan melalui metode ilmiah yang sistematis. Model pembelajaran ini mampu meningkatkan dan membudayakan keterampilan berpikir sains siswa (Hasibuan, Permana Sari, \& Setiawaty, 2019). Melalui pendekatan saintifik juga mampu meningkatkan hasil belajar siswa secara efektif (Yunita, 2019)

Pendekatan saintifik didesain agar siswa secara aktif mampu mengkonstruk konsep, hukum atau prinsip melalui tahapan mengamati untuk mengidentifikasi, merumuskan, membuat hipotesis, mengumpulkan data, menganalisis data hingga menarik suatu kesimpulan. Selain itu melalui pembelajaran saintifik siswa juga diharap dapat mengomunikasikan sebuah konsep, hukum atau prinsip yang ditemukan berdasarkan pemahamannya tanpa terpaku pada buku teks (Karar \& Yenice, 2012). Adapun langkah-langkah pendekatan saintifik dalam pembelajaran dikenal dengan $5 \mathrm{M}$ meliputi mengamati, menanya, mengumpulkan informasi, mengasosiasi atau mengolah informasi dan mengkomunikasikan. 
Mata kuliah Perencanaan Pembelajaran merupakan mata kuliah yang membahas dan menyusun perangkat pembelajaran. Salah satu hasil akhir mata kuliah ini yakni mahasiswa mampu mengembangkan RPP dengan pendekatan saintifik sebagai lulusan pendidikan kimia yang nantinya akan menjadi guru, sehingga harus mampu menyusun perangkat pembelajaran dengan baik. Salah satu tujuan dari penelitian ini yaitu untuk mengetahui kemampuan atau keterampilan mahasiswa dalam menyusun kegiatan pembelajaran berbasis pendekatan saintifik yang dituangkan dalam sebuah RPP. Penelitian ini dilakukan untuk mempersiapkan mahasiswa sebagai calon guru yang nantinya ketika memasuki dunia kerja sebagai guru diharuskan memiliki keterampilan dalam menyusun perangkat pembelajaran. Dengan penelitian ini diharapkan mahasiswa lebih terampil dalam penyusunan rencana kegiatan pembelajaran berbasis saintifik yang tertuang dalam sebuah RPP.

Tabel 1. Indikator aktivitas mahasiswa dalam merancang pembelajaran berbasis saintifik yang dituangkan dalam RPP

\begin{tabular}{ll}
\hline Aspek & Indikator \\
\hline Mengamati & $\begin{array}{l}\text { Kegiatan mengamati dilakukan dengan mengamati atau mengobservasi antara objek } \\
\text { yang dianalisis dengan materi pembelajaran yang digunakan oleh guru. }\end{array}$ \\
Menanya & $\begin{array}{l}\text { Kegiatan belajar menanya dilakukan dengan cara mengajukan pertanyaan tentang } \\
\text { informasi yang tidak dipahami dari apa yang diamati atau pertanyaan untuk } \\
\text { mendapatkan informasi tambahan tentang apa yang diamati. }\end{array}$ \\
Mengumpulkan Informasi & $\begin{array}{l}\text { Kegiatan ini dilakukan dengan menggali dan mengumpulkan informasi dari berbagai } \\
\text { sumber melalui berbagai cara yakni dapat membaca berbagai sumber, } \\
\text { memperhatikan fenomena atau objek yang lebih teliti, atau bahkan melakukan } \\
\text { eksperimen. }\end{array}$ \\
Mengasosiasikan/mengolah \\
informasi \\
Mengkomunikasi & $\begin{array}{l}\text { Kegiatan ini yakni proses berfikir yang logis dan sistematis atas fakta-fakta empiris } \\
\text { yang dapat diobservasi untuk memperoleh simpulan berupa pengetahuan. }\end{array}$ \\
& $\begin{array}{l}\text { Kegiatan ini dapat dilakukan melalui menuliskan atau menceritakan apa yang } \\
\text { ditemukan dalam kegiatan mencari informasi, mengasosiasikan, dan menemukan } \\
\text { pola }\end{array}$ \\
\hline
\end{tabular}

Selanjutnya data hasil pengamatan dihitung dengan rumus (a) untuk mencari persentase kemampuan mahasiswa dalam menyusun rencana pembelajaran dengan pedekatan saintifik:

\section{METODE PENELITIAN}

Penelitian ini merupakan penelitian kualitatif. Gambaran hubungan yang akurat karakteristik suatu fenomena menjadi fokus utama penelitian deskriptif (Johnson \& Christensen, 2014). Sedangkan penggunaan pendekatan kualitatif bertujuan untuk mengungkap suatu masalah dan menjabarkan secara mendalam untuk memahami pusat peristiwa dari sebuah masalah (Creswell \& Guetterman, 2018). Populasi dalam penelitian ini adalah seluruh mahasiswa Pendidikan Kimia Uin Walisongo Semarang semester 5 yang mengambil matakuliah Perencanaan Pembelajaran. Sampel dalam penelitian ini yakni 25 orang. Instrumen pengumpul data berupa angket analisis pendekatan saintifik pada RPP. Berikut instrumen yang dimodifikasi dari langkahlangkah pendekatan saintifik dengan skor skala linkert (Daryanto, 2014). 


\section{HASIL DAN PEMBAHASAN}

Sebelum menganalisis pendekatan saintifik dalam tahapan kegiatan pembelajaran pada RPP terlebih dahulu mahasiswa menyusun RPP sesuai kurikulum 2013. Kemudian menganalisis pendekatan saintifik pada tahapan kegiatan pembelajaran yakni pada kegiatan inti. Hasil analisis pendekatan saintifik pada RPP lebih jelasnya pada tabel 2 .

Tabel 2. Hasil Analisis Pendekatan Saintifik pada RPP

\begin{tabular}{lll}
\hline Aspek & Skor & Persentase \\
\hline Mengamati & 83 & $83 \%$ \\
Menanya & 80 & $80 \%$ \\
Mengumpulkan Informasi & 75 & $75 \%$ \\
Mengasosiasikan atau & 76 & $76 \%$ \\
Mengolah Informasi & & \\
Mengkomunikasikan & 81 & $81 \%$ \\
\hline
\end{tabular}

Dari tabel tersebut diperoleh dari 25 sampel menunjukkan kemampuan pada tahap mengamati yakni $83 \%$, menanya $80 \%$, mengumpulkan informasi $75 \%$, mengasosiasikan/mengolah informasi $76 \%$ dan mengkomunikasikan $81 \%$. Hasil tersebut lebih jelasnya pada gambar 1 .

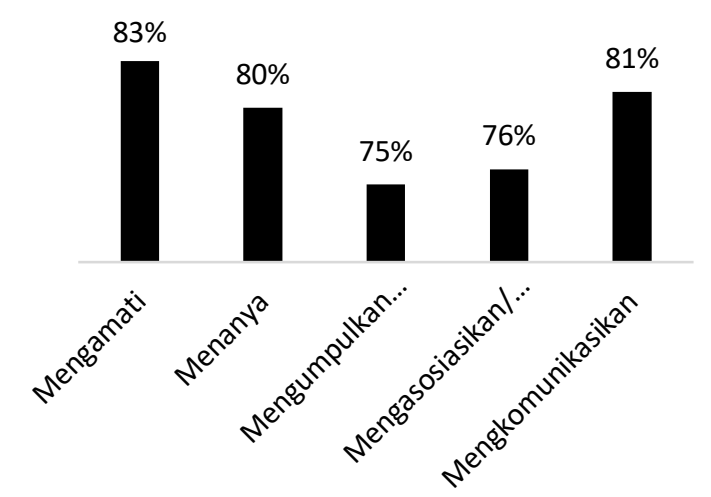

Gambar 1. Hasil Analisis Pendekatan Saintifik

Dari data tersebut diperoleh bahwa persentase tahapan yang paling tinggi yaitu mengamati. Hal ini dibuktikan dengan ratarata mahasiswa menyusun tahapan mengamati dengan memberikan video yang berhubungan dengan materi yang akan diajarkan. Kemudian pada tahap mengamati tersebut dapat dilakukan dengan audio, visual, audio visual sehingga mahasiswa memiliki banyak ide dalam menyusun kegiatan pembelajaran pada tahap mengamati. Persentase tahapan yang paling rendah yaitu mengumpulkan informasi. Menurut mahasiswa, mereka masih mengalami kesulitan saat menghubungkan pendekatan saintifik yaitu tahap mengumpulkan informasi dengan model pembelajaran yang digunakan. Melalui pendekatan saintif dalam pembelajaran, siswa akan dilatih untuk meningkatkan keterampilan berpikir kritis, menyelesaikan berbagai masalah secara sistematis, menanamkan pemikiran bahwa belajar merupakan suatu kebutuhan, menemukan berbagai ide serta mampu mengkomunikasikannya, meningkatkan hasil belajar dan mengembangkan karakter.

Pembelajaran dengan menggunakan pendekatan saintifik terbukti memiliki efektivitas yang tinggi dalam meningkatkan hasil belajar siswa pada aspek kognitif pada jenjang pengetahuan, pemahaman, dan penerapan (Nurohmah, 2015). Pembelajaran menggunakan pendekatan saintifik juga memungkinkan untuk digunakan dalam melatih literasi saintifik siswa (Wahyuni, 2018). Oleh karena itu mahasiswa sebagai calon guru diharapkan mampu menyusun perangkat pembelajaran dengan baik terutama dengan menggunakan pendekatan saintifik.

Berdasarkan hasil penelitian, menunjukkan perlu adanya tindak lanjut untuk terus meningkatkan kemampuan mahasiswa agar lebih terampil dalam menyusun RPP berbasis saintifik. Karena kemampuan dalam mengembangakan rencana pembelajaran akan sangat dibutuhkan oleh mahasiswa nantinya sebagai calon guru ketika sudah terjun ke masyarakat dan mengabdi dalam dunia pendidikan.

\section{SIMPULAN}

Berdasarkan hasil pegamatan dan analisis data pada saat penelitian maka dapat diketahui bahwa kemampuan mahasiswa 
dalam merencanakan pembelajaran dengan pendekatan saintifik pada sebuah RPP masih perlu untuk ditingkatkan sebagai calon guru dimasa depan, dimana persentase kemapuan mahasiswa pada tahap mengamati sebesar

\section{DAFTAR RUJUKAN}

Amalia, S. P., Naswir, M., \& Harizon, H. (2020). Pengembangan Multimedia Interaktif Berbasis Pendekatan saintifik materi larutan elektrolit dan non elektolit. Journal of The Indonesian Society of Integrated Chemistry, 12(1), 9-15. https://doi.org/10.22437/jisic.v12i1.857 0

Apriyanto, C., Yusnelti, Y., \& Asrial, A. (2019). Pengembangan E-LKPD berpendekatan saintifik larutan elektrolit dan non elektrolit. Journal of The Indonesian Society of Integrated Chemistry, 11(1), 38-42. https://doi.org/10.22437/jisic.v11i1.684 3

Creswell, J., \& Guetterman, T. (2018). Educational research: Planning, conducting, and evaluating quantitative and qualitative research ( 6 ed.).

Daryanto. (2014). Pendekatan pembelajaran saintifik kurikulum 2013. Yogyakarta: Gava Media.

Depdikbud. Peraturan menteri pendidikan dan kebudayaan Republik Indonesia Nomor 103 Tahun 2014 tentang Pembelajaran Pada Pendidikan Dasar adan Pendidikan Menengah., (2014).

Hasibuan, M., Permana Sari, R., \& Setiawaty, S. (2019). Penerapan model pembelajaran dengan pendekatan saintifik terhadap pembentukan habits of mind siswa. Jurnal IPA \& Pembelajaran IPA, 3, 119-129. https://doi.org/10.24815/jipi.v3i2.1441 5
$83 \%$, menanya $80 \%$, mengumpulkan informasi $75 \%$, mengasosiasikan/mengolah informasi $76 \%$ dan mengkomunikasikan 81 $\%$.

Johnson, R. B., \& Christensen, L. (2014). Educational research quantitative, qualitative, and mixed approaches (4 ed.).

Karar, E., \& Yenice, N. (2012). The investigation of scientific process skill level of elementary education 8th grade students in view of demographic features. Procedia - Social and Behavioral Sciences, 46, 3885-3889. https://doi.org/10.1016/j.sbspro.2012.0 6.166

Nurohmah, E. F. (2015). Efektivitas pendekatan saintifik dalam meningkatkan hasil dan motivasi belajar siswa SMP. Universitas Pendidikan Indonesia.

Wahyuni, S. (2018). Implementasi pendekatan sainstifik pada pelajaran biologi untuk meningkatkan hasil belajar kognitif dan keterampilan sains siswa kelas XI-IPA SMA Negeri 2 Lambandia, Kab. Kolaka Timur- Sultra. Jurnal Pendidikan Biologi, 9(2).

Yunita. (2019). Pendekatan saintifik pada topik sel volta. EduChemia (Jurnal Kimia dan Pendidikan), 4, 49. https://doi.org/10.30870/educhemia.v4i 1.5198 